\title{
The Factory as a Battlefield
}

\section{HELENA CHÁVEZ MAC GREGOR}

Instituto de Investigaciones Estéticas, Universidad Nacional Autónoma de México

The crisis of labour is also one of representation. Some contemporary artists working with moving images have been questioning how to represent capital, labour and the worker. Isaac Julien or Harun Farocki, for example, have focused on interlacing characters - from fiction or reality - with geopolitical spaces in order to present the entanglement of the economical new order with the new forms of labour. The South African artist Simon Gush has shifted from this trend in order to present labour without directly representing the workers. In his artwork there is no longer a search for the political subject as a historical force or for the individuals who occupied its place; instead he leads viewers to a critical reading of an object, allowing a staging of the past from the viewpoint of the present. That is what I think Red does. In this article I explore Gush's connections with Marx, Benjamin and Steyerl to show how Gush's work is part of a critical tradition that has abandoned the subject as the privileged instance of political agency; turning the emphasis of the modern schema upside down, it focuses on the object as the force of emancipation. I would like to suggest that Gush used an object, Mandela's red Mercedes-Benz, to produce another image so that the story told is not necessarily that of a symbol of pacification, but one in which the factory was a battlefield. In this way I explore the emancipatory potencies of the object. What I propose is a reading of Red from the point of view of a return to the thing, where the latter becomes a political force.

Since 2013 Simon Gush has concentrated his artistic practice on the theme of labour. Although he makes use of different modes of presentation, his most forceful works take the form of visual essays in moving images. ${ }^{1}$ Works such as Lazy Nigel (2013), Iseeyou (2013), Sunday Light (2013), After Hours (2013) and After the Work Stopped (2013-) offer a contraposition of the lyrical and the disturbing. While the images Gush works with are of exceptional beauty (generated almost always in black and white), they generate a sense of aloneness that distils the contradiction of a past that has signified the human through mankind's capacity for work, and a present in which labour becomes blurred, immaterialised, or disappears from view.

The accent in these pieces falls on labour explored in terms of its emptying out, so as to introduce - through the rupture of the classic representation of labour a challenging of time, space and history. In this sense, the work of Gush departs from cinematic productions that presented labour through its direct representation. 
According to the artist himself, this translates, in the South African context, to distancing himself from the old apartheid approach:

Apartheid representations of labour are propagandist and coercive where black bodies are always presented in the first place as workers; Trade Union documentaries offer celebrations of work, which erase the ideological problems of work .... I am against the notions of truth in this mode. Mining archive footage offers a medical, scientific, or engineering viewpoint. This was the kind of archival footage produced during apartheid, often by the mining companies, where workers become cogs in the machine. ${ }^{2}$

Sidestepping the heavy weight of these traditions of the image in relation with labour, the work of Gush offers a critique of representation in which the image seems to question history with shots of places emptied of work that take on another spatiality under the light of a time without activity. The reflections of the artist - which, in almost all his works, comprise a sort of personal essay in which the artist is aware of his enunciation as a white male - update a series of questions on labour where what is almost always absent is the worker.

To present work in the absence of the worker seems paradoxical for an aesthetics that used the figure of the worker to symbolise processes of subjectification giving rise to social and civil action, in which forms such as 'worker', 'proletariat', 'peasant' or 'people' joined to make a collective statement to generate a claim, on the basis of equality, for fairer working and living conditions. These forms of subjectivity serving the goals of emancipation have been seriously damaged in the last twenty years so that 'workers' and other such historical subjects have become fragmented, isolated and diminished as a political force.

With the consolidation of neoliberalism, the order and distribution of the forces that organise capital (living labour, nature, technology and science) ${ }^{3}$ have been realigned, transforming the world completely. Privatisation of public properties and services, deregulation of work so as to cheapen labour, erosion of workers' systems of trade union and social organisation in order to break down resistance to the restructuring of social rights previously won, have been the constants of a systematic political and economic process.

As the historian Adolfo Gilly points out, this process began in the 1980s with trade union disputes that led to intense social struggles. One might think of the air traffic controllers' strike in the United States under Ronald Reagan's presidency in 1981, or the miners' strike in Great Britain in 1984 under Margaret Thatcher. Later, these struggles were subsumed in a globalisation of the market that unleashed a process of appropriating common goods, leading to a systematic despoilment. These conditions had direct effects on the transformation of work and its political sphere. As Gilly states, 'with specific forms for each territory, the decline of wages in the

Simon Gush in mail conversation, 19 June 2006.

The matrix that Marx explores to explain capital. 
world of work knew no exceptions and was accompanied by its shadows: informal work, biblical migrations, migrants deprived of rights and the weakening of social organization. ${ }^{4}$

Labour has been transformed, but if we compare this process with previous transformations spanning long periods, the time of this mutation has been relatively short. Hence those older representations of the workers in sculpture, painting and cinema still create tension in our imaginaries and, while it is important to bear them in mind in order to retain a testimony to the past, we urgently need to generate new elements or forms, as sensible configurations, to think about the present. Yet how can one represent these economic processes? And within them, how can one present the worker and work? Can the blueprint of emancipation based on the historical agency of the subject still guide the process of political struggle?

\section{Capital and the Representation of Labour}

Much of the critical reflection on economics of recent years - we might think of the work of Franco Berardi 'Bifo', Maurizio Lazzarato or David Harvey, for example - has centred on questioning this moment of capital in order to understand whether the classic terms in which Marx described it still apply or whether this transformation, described as semiocapitalist, offers a new series of abstractions that require a new vocabulary. What is clear is that the very possibility of representing this new economic conformation is challenged by an ever greater complexity; and, in the field of art, this complexity has stimulated a powerful current of inquiry into the relation between image and representation. ${ }^{5}$ Discussing with the British artist Isaac Julien just why capital is so difficult to represent, Harvey says:

It's a bit like gravity: you can't grab it; you can't hold it; you can't smell it or touch it; it's a very powerful force; it's a relationship which makes things happen. And in the same way, you can only intuit gravity exists by its effects. The apple falls from the tree and you say 'Oh, it must be gravity'. The factory closes down and you say, 'Ah, it must be capital'. So, it's that intangibility. And actually, the language Marx uses is that it's material but objective. And I find very important always to keep in mind, so that you don't imagine that you could actually grasp it in physical form ... ${ }^{6}$

4 Adolfo Gilly and Rhina Roux, El tiempo del despojo: Siete ensayos sobre un cambio de época (Mexico City: Editorial Ítaca, 2015), 27.

5 I am interested in situating the work of Gush in this tradition that sets off from a generation of artists such as Isaac Julien and Harun Farocki, who began their careers as film makers yet began to move towards a practice closer to contemporary art. This displacement towards the circuits of contemporary art implies, among other things, a circulation and montages different from those offered by the cinema. This tendency is something that film makers like Jonas Mekas, or the maker of experimental documentaries Trin Minh-ha, have explored in recent years. In works such as those of Julien, Farocki or Steyerl, it marks a tradition akin to that of the moving image in contemporary art - one characterised by a questioning of representation and image. In this sense I believe that Gush's work must be read from this tradition rather than from those of other schools or movements of visual production, since his concern seems also to be directed at how to produce images and present them in a form and circulation proper to contemporary art.

6 Isaac Julien,'Transcription from Kapital' in Isaac Julien, Isaac Julien: Playtime \& Kapital (Mexico City: MUAC-UNAM, 2016), 83. 
In view of the difficulty of proposing a representation of capital, what Julien presented was the discussion itself. Kapital (2013) is the record of the conference 'Choreographing Capital' which took place at the Hayward Gallery in 2012, with the participation - besides Harvey and Julien - of Stuart Hall, Irit Rigoff, Paul Gilroy and Colin MacCabe. This work Kapital aims to reconstruct how to represent capital, and the image it presents is that of the abstraction of several concepts of capital in the voices of various theoretical approaches.

It is interesting that, although Harvey asserts the intangibility of capital, here he states the belief that its effects still enable us to think about the present-day economy along the lines of Marx's theory and to read in all this variety of work situations a great productive force which we could still call 'proletariat'. He seems to suggest that, while capital cannot be represented, labour (even in its fragmentation) could be seen in that urban mass as part of a single working class. That is to say, despite the drastic changes in the class structure, an early morning journey on the subway to Manhattan - which is where Harvey had this revelation - clearly shows the continuing existence of the modern proletariat. In contrast, Stuart Hall questions Harvey's revisionism, insisting on the elements that fragment the supposed 'unity' of the workers and asking whether there really is anything that nowadays might correspond to the figure of the proletariat:

What unifies that complex and diverse class formation, 'the modern urban poor'? It now includes men and women, white and black, the long term unemployed, the single-parent mother, people whose family relations have broken down, the vulnerable, the destitute, the marginalized, social misfits, dropouts, rough sleepers, the chronically ill or addicted, illegal immigrants, and asylum seekers without papers. Few of these could be described as exchanging their labour 'productively' against capital. Is this a 'proletariat' in the classic sense? Do they share a common class position or consciousness with today's technologically high skilled workforce? Marx spoke of the 'lumpen proletariat': what became of them? Expanded to include everyone but the wealthy one percent, the term loses its historical specificity. ${ }^{7}$

This loss of historical specificity is what matters to us. If capital is difficult to represent, so is the worker. And this has become a problem since the tension surrounding the representation of labour faces a multiplicity of heterogeneities that has made a collective enunciation impossible. If what has disappeared is the worker as a historical subject, how are we to create an image of labour?

An interesting option has been to present the personages of labour, no longer as a unified social force but as micro-narratives that open upon the complex panorama of the present-day labour scenario. In this sense we can understand the work Playtime (2014) by Julien in which he stages different scenes from financial capitalism in an 
interlacing of characters from fiction with geopolitical spaces where a series of contemporary landscapes is developed: a hedge fund administrator, an Icelandic artist relating the financial collapse of 2008 , an art dealer discussing a work of art in a white cube with some journalists and the chairman of an auction company, and a Philippine domestic worker trapped in Dubai. Although there is no representation of the historical subject as such, there is a display of possible scenarios where the characters are situated in economic frameworks that to some extent determine their roles.

Another type of visual production that has opened a vista on current forms of labour was the final investigation by the artist Harun Farocki before his death. Farocki had, of course, been engaged since the 1990s in productions like the film Workers Leaving the Factory (1995) and the multichannel video installation Workers Leaving the Factory in Eleven Decades (2006), works that explore the relation of the moving image to the factory and demonstrate how the history of the cinema produced classic representations of the worker. Between 2011 and 2014, Farocki with Antje Ehmann carried out the project Labour in a Single Shot. In workshops discussing 15 of the world's cities (Bangalore, Berlin, Boston, Buenos Aires, Cairo, Hangzhou, Geneva, Hanoi, Johannesburg, Lisbon, Lodz, Mexico City, Rio de Janiero, Moscow and Tel Aviv) they worked with other film and video makers in search of representations in a single shot that would portray images of labour in the different geographical and political locations. The videos that make up this project represent a grammar of labour through which to further the critical enterprise of opening eyes.

Often labour is not only invisible but also unimaginable. Therefore it is vital to undertake research, to open one's eyes and to set oneself into motion. Where can we see which kinds of labour? What is hidden? What happens in the centre of a city, what occurs at the periphery? What is characteristic and what is unusual with regard to each city? What kinds of labour processes set interesting cinematographic challenges?

The multiplication of activities and the forms acquired by labour today respond to the continuing climate of economic crisis, and one of the many consequences of this process is the fragmentation of a working class that was once the subject of a unified representation. There is labour but there is no longer a historical subject permitting a collective enunciation.

While the line embarked on by Julien and Farocki is extremely interesting in opening eyes to present-day scenarios, there is another possibility that I would like to explore. Here the modern scheme of agency of the subject is turned upside down so that the object makes its appearance as a historical potency; ${ }^{9}$ there is no longer

Harun Farocki and Anje Ehman, 'Concept', http://www.labour-in-a-single-shot.net/en/project/concept/, accessed 23 June 2016.

9 One of the bases of modern experience is the subjugation of the object towards the subject. In that scheme, modernity guaranteed autonomy and sovereignty, generating the subject as a political, historical and ontological substance. In this sense the subject has created an agency. It is well known that since the twentieth century the subject as a category of dominant subjectivity has been put in question. What we address here is not the critique of the subject as a dominant structure of modernity but the way some authors and artists have explored the potential of the object to create another political agency. Doing so, they have inverted the earlier take on experience and political emancipation. 

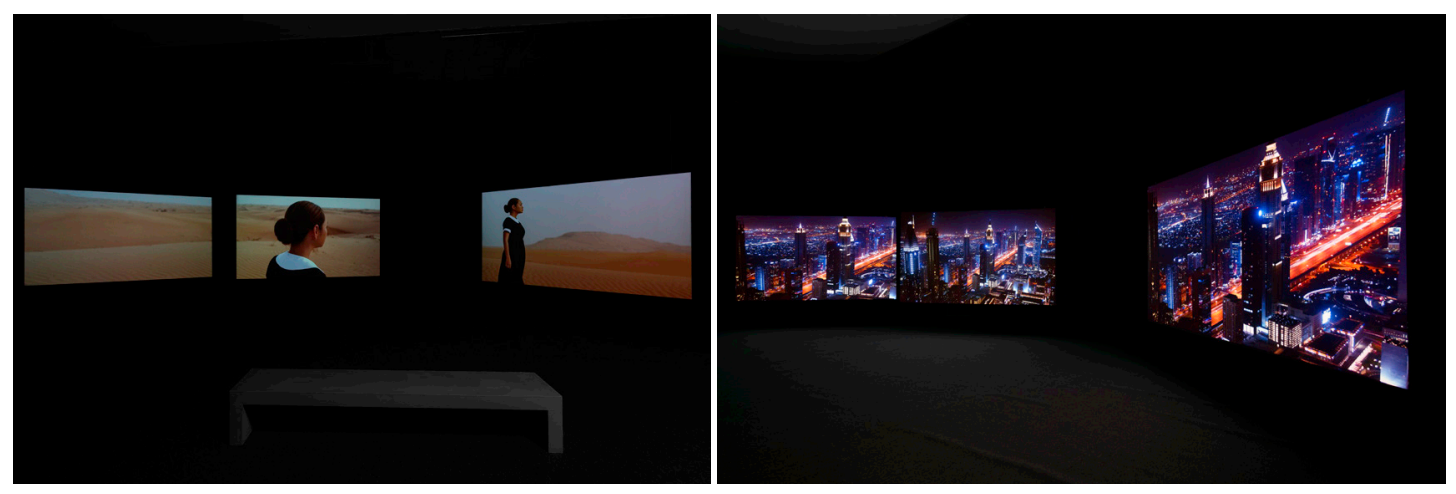

Figure 1: Views of the exhibition 'Isaac Julien: Playtime \& Kapital', Museo Universitario Arte Contemporáneo, 2016. Photo: Oliver Santana, courtesy of MUAC-UNAM

Figure 2: Views of the exhibition 'Isaac Julien: Playtime \& Kapital', Museo Universitario Arte Contemporáneo, 2016. Photo: Oliver Santana, courtesy of MUAC-UNAM
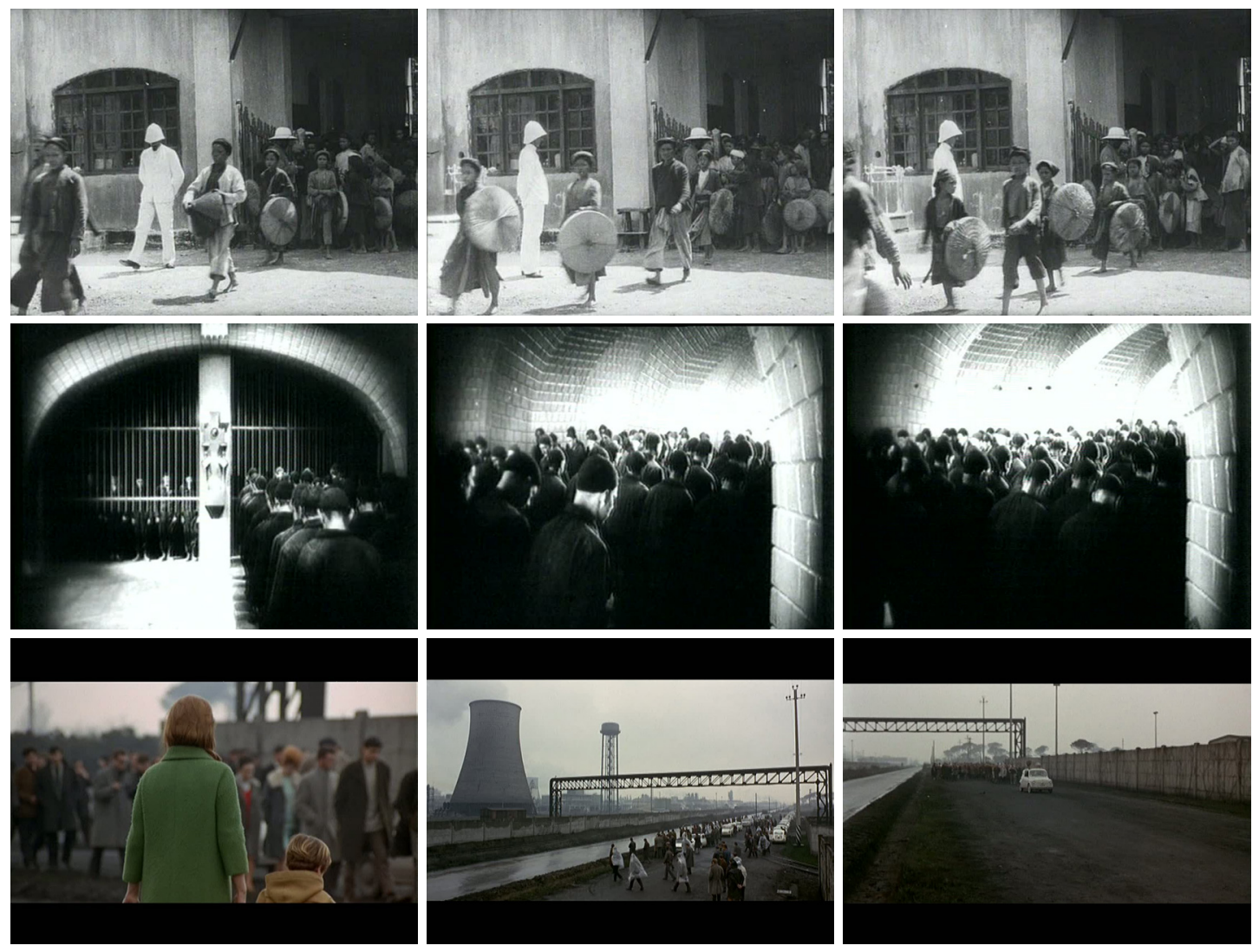

Figure 3. Harun Farocki, Workers Leaving the Factory in Eleven Decades, 2006. Video installation for 12 monitors, 36 min. Photo courtesy of Àngels Barcelona Gallery 
a search for the subject or the individuals who once occupied that place. What this enables is a critical reading of the object, allowing a staging of the past from the viewpoint of the present. This is what I think Red achieves.

\section{The Return to the Thing}

While Simon Gush's earlier works on labour had featured the emptying of representation, turning reflection into an almost poetic construction of space and time, his work Red (2014) took a radical departure in searching for a historical inflection. The tension in this work relates to an object: Mandela's red Mercedes-Benz.

This object, so often alluded to in telling 'the story of a labour of love, ${ }^{10}$ was a gift from the workers of Mercedes-Benz in the city of East London in 1990 to the future president of South Africa on his release from prison after 27 years of captivity. The object has been inscribed in history as an icon of the process of reconciliation, stemming as it does from cooperation between workers and management. Nonetheless, Gush returned to this object in order to produce another image so that the story it opens up is not necessarily that of a symbol of change, but one in which the factory was a battlefield.

Red is made up of several works: Red, a film ( 81 min $49 \mathrm{sec}$ ) made in collaboration with James Cairns; Red (sleep-in strike beds); Red (strike uniforms) in collaboration with Mokotjo Mohulo; and Red (Mandela car). Installed as a set, the film enters in tension with these objects that were never represented as such in it. At first sight, the film appears to be a documentary presenting the memory of a conflict through the narration of some of those who took part. However, although there is certainly an account of events surrounding the production of Mandela's red Mercedes, the artist resists any impulse to generate a representation of the workers. There is neither archival material nor shots of workers in the factory, just the factory emptied of workers, which, in contrast to the narrative, seems to boycott the spectator's longing for a heroic vision. ${ }^{11}$

There is no epic in Red. Here labour, both in the film and in the installations, is seen only in the return to the object (although in a fictional manner), in this case the car, so as to seek the emancipatory potencies of history. Thus what I propose is a reading of Red from the point of view of a return to the thing, where the latter becomes a political force.

A return to the thing: because, as we shall see, the thing has always been there lurking, awaiting its moment to speak about history, setting the modern aesthetic schema back to front. If Kant's Copernican revolution consisted of an epistemological project that suppressed the harmony between the subject and the object under a superior order (final concordance) in order to impose a necessary subjection of the

10 The Mercedes-Benz company itself tells the heroic tale of a negotiation that, as it would have it, represents an alliance between the firm and its workers. That moment thus becomes an icon of South African unification, forgetting the industrial conflict that broke out shortly afterwards. See https://www.youtube.com/watch?v=ZLtYr3d0wvs, accessed 23 July 2016.

See Images 6-8 of Gush's photo essay in this issue. 
object to the subject, we shall see how the productions of artists like Gush and Steyerl stage a revolt of the object in which it is the latter that produces meaning, thereby making possible a different version of history.

This centring on the thing sets off from Marx, who in texts like A Contribution to the Critique of Political Economy (1859) considers the relation of production and consumption in order to critique the privilege of the subject over the object. What Marx stresses in the production of artistic objects is that these, like any other objects of capitalist production, also produce the subjects that consume them: 'Production accordingly produces not only an object for the subject, but also a subject for the object.' ${ }^{12}$ Marx thinks of history from the point of view of the object: the object is history to the extent that it expresses the social forces of the mode of production.

Although various authors took up these notions within one or other current of historical materialism, I am interested in pausing a moment for Walter Benjamin, who made the radical proposal of seeing in the aesthetic experience of the thing a process of emancipation for the subject. For Benjamin, the thing is what allows one to unfold an emancipatory experience by confronting the forces that had produced it, thus initiating a new Copernican revolution.

For Benjamin, the dreams of modernity, in the light of technology, are petrified in objects that became the phantasmagoria of an era. The phantasmagoria, central to his writings of the 1930s, points to the way in which capitalist merchandise presses to generate a reality that is taken as natural and given (concealing the fact that it is a socioeconomic construct). In the light of these readings of the merchandise, the critical task for Benjamin was to find that failed promise in objects, in images, in architecture; and to look, as Ricardo Ibarlucía states in his analysis of the relation between Benjamin and Surrealism, for 'the space where the dreams of an era become immobilised inscribing on the fetish of the merchandise "the word history with the characters of transience."'13

From 1927, Benjamin conceived an inquiry that was to run parallel with all his concerns. In his project, called 'Passagen-Werk', he sought to express the feeling of vertigo that characterised the nineteenth-century conception of history, which 'corresponds to a viewpoint according to which the course of the world is an endless series of facts congealed in the form of things. ${ }^{14}$ Benjamin goes in search of the expressive character of the first industrial products, the first iron buildings, the first machines, the first shops, the posters, the trinkets - in other words, all the objects with which modernity dominates the world by means of its phantasmagoria.

The Passagen-Werk is a work of montages, one that takes up the monumental dreams of reason that are manifested in objects, while inheriting the view of the Surrealists. Benjamin maintained that 'philosophy not only must embrace surrealism,

12 Karl Marx, A Contribution to the Critique of Political Economy. See https://www.marxists.org/archive/marx/works/1859/critiquepol-economy/appxi.htm. Last accessed 2 December 2016.

13 Ricardo Ibarlucía, Onirokitsch: Walter Benjamin y el surrealismo (Buenos Aires: Manantial, 1998), 67-8.

14 Walter Benjamin, The Arcades Project (Cambridge MA: Belknap/Harvard University Press, 1999), 14. This work is a translation of Benjamin's notes written between 1927 and 1940 on the emergence of urban commodity capitalism in mid-nineteenthcentury France. It was published after his death. 
but must be surrealist itself. ${ }^{\prime 15}$ And this meant seeking in objects the oneiric (dreamlike imagery) stratum and not their stratum of promise, of ideal, in order to find the meaning that leaves no aura of nobility, so as to allow the history that has been buried by the phantasmagoria of progress to emerge. For Benjamin, what starts to tumble when subjected to the Surrealist view is the use value, laying bare - now stripped of the influence of bewitchment - the process of production of the thing as merchandise.

In this sense, Benjamin follows Marx on the historical character of things, but he does so in order to move towards process of emancipation of the subject. The experience of these objects, the tension between their promise and their failure, would set off, according to Benjamin, a Copernican revolution in which the structure of progress is dismantled in a 'flash of cognoscibility'. The thing, seen through that Surrealist aperture, would strike the subject in such a way as to display a view of history from the present, and not under the enchantment exercised by the past over the future.

The Copernican revolution in historical perception is as follows. Formerly it was thought that a fixed point of view had been found in 'what has been', and one saw the present engaged in tentatively concentrating the forces of knowledge on this ground. Now this relation is to be overturned, and what has been found is to become the dialectical reversal - the flash of awakened consciousness. Politics attains primacy over history. The facts become something that just now first happened to us, first struck us; to establish them is the affair of memory. Indeed, awakening is the great exemplar of memory: the occasion on which it is given us to remember what is closest, tritest, most obvious. ${ }^{16}$

For Benjamin, the thing does not attempt to affirm the subject, but rather - if one succeeds in viewing it from the oneiric state - completely to dismount capitalism's forms of domination that discovered in the phantasmagoria of merchandise a way of concealing the mode of production and thus producing the enchantment. For Benjamin, emancipation lies in subjects breaking the spell and thus conceiving another history. In this process politics takes primacy over history and urges the subject towards an emancipation that will prove revolutionary.

The latter half of the twentieth century insisted that the process of transformation could be guided by this emancipated subject, a historical subject that would overturn the forms of domination. Now, with the twenty-first century under way, this subject seems to have become fragmented and to have lost in its own agency. How then is one to insist on an emancipatory programme? 


\section{The Thing Speaks for Itself}

Some artists now seem to want to give the schema another turn of the screw in order to return to the thing - no longer, as Benjamin hoped, in order to provoke a revolt in the subject, but to let the thing speak. This is how the artist and theoretician Hito Steyerl puts it:

Traditionally, emancipatory practice has been tied to a desire to become a subject. Emancipation was conceived as becoming a subject of history, of representation, or of politics. To become a subject carried with it the promise of autonomy, sovereignty, agency. To be a subject was good; to be an object was bad. But, as we all know, being a subject can be tricky. The subject is always already subjected. Though the position of the subject suggests a degree of control, its reality is rather one of being subjected to power relations... But as the struggle to become a subject became mired in its own contradictions, a different possibility emerged. How about siding with the object for a change? Why not affirm it? Why not be a thing? An object without a subject? A thing among other things? ${ }^{17}$

Steyerl's critical operation sets off from the failure of the emancipatory struggles of the twentieth century that placed their accent on the subject; perhaps, the artist suggests, the possibility is now in the thing, in searching in it for the possibilities of appearing, that is to say, of interrogating, of doing history. This schema starts by questioning the epistemological model of modernity where the thing is always passive. This approach, while it originates in Marx and the historical production of the thing, also activates other anthropological and philosophical traditions that have found it necessary to posit the agency of the thing in order to propose other social, political and economic systems. ${ }^{18}$

These ideas can be found in the theoretical work of Steyerl, and they are also present in her art. This German artist has been working for more than a decade on producing a critical image to restore the political possibilities of the image in an era of visual saturation. Several of her works set things at the centre of an inquiry and the device turns in such a way as to make history speak.

One of the most striking examples is in her work Adorno's Grey (2012). In this film installation the artist takes up an old rumour that the lecture room where Adorno gave classes was painted grey. Here Steyerl sought her entry point in an investigation conceived as a restoration, bringing to mind an archaeological or forensic operation,

17 Hito Steyerl, Los condenados de la pantalla (Buenos Aires: Caja Negra, 2014), 52.

18 The relation posited by modernity between subject and object has been a constituent of a dominant Weltanschauung which ignored other epistemic, aesthetic and political possibilities. It is important to consider this above all because of the consequences it was to have for capitalism and its forms of exploitation. In the mid-twentieth century this model of relations was challenged by anthropology and critical theory for failing to entertain the focus on common objects that was already present in Zola. Recent critical theory has tried to incorporate agency into objects rejected by modernity and to propose new forms of experience that are not constrained by the sovereignty of the subject, understood as having the absolute right to dominate and exploit things. Authors such as Alfred Gell, Eduardo Viveiro de Castro and Hito Steyerl, among others, draw attention to fissures in the homogeneous model of experience as set forth by modernity and expounded as a world system. 


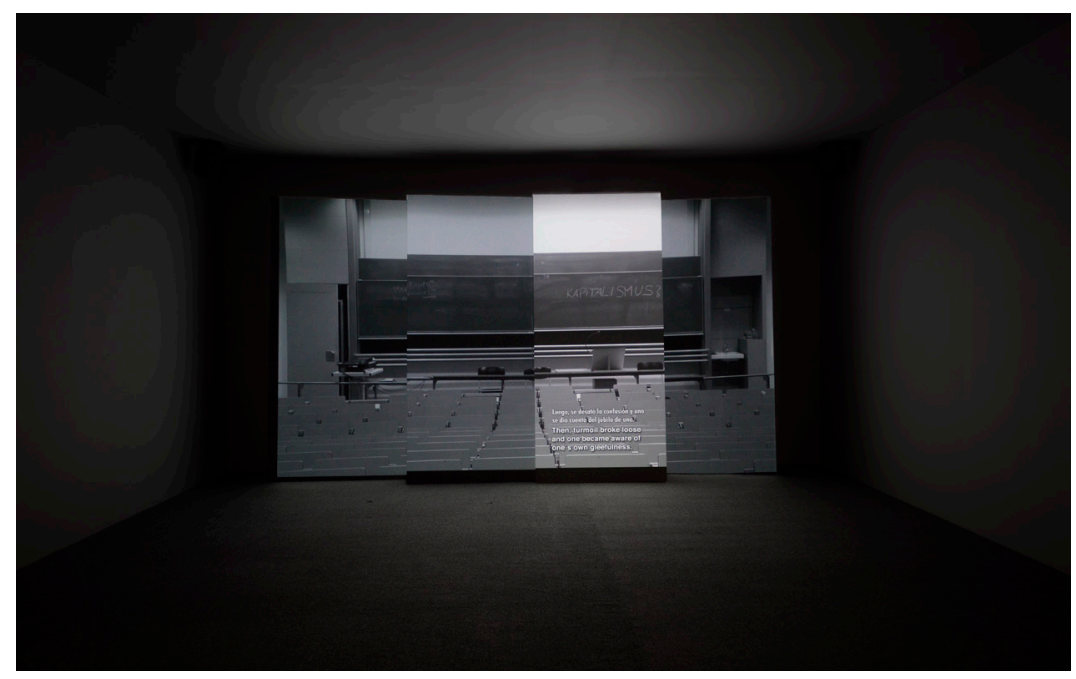

Figure 4: Views of the exhibition 'Hito Steyerl: Circulationism', Museo Universitario Arte Contemporáneo, 2014. Photo: Oliver Santana, courtesy of MUAC-UNAM

which aimed not only at corroborating the fact but at letting this colour act as witness for revealing what it was that happened in Adorno's last lesson.

On 22 April 1969 at the Goethe University in Frankfurt am Main a group of female students exposed their breasts in the middle of a lesson given by Adorno. The students, belonging to the Leather Jacket Fraktion of the SDS organisation (Sozialistische Deutsche Studentenbund), bared themselves and danced around the professor. Adorno collected his papers and left the room. That was to be Adorno's last lesson. The philosopher died a few months later without finishing his final work, later published as Aesthetic Theory. Many have speculated that the Busenattentat (breast attack) may have been one of the events that led to the death of the famous theoretician.

Why should this act have led Adorno never to resume his session and to abandon teaching at the university? Surely it was not the breasts themselves that alarmed him but the discordance. The event was marked by an irreparable fracture between a way of understanding the function of theory in political practice and the student movement. ${ }^{19}$

Hito Steyerl seeks the thing as a witness, and, on not finding it, she fictionalises it. After scraping away layer after layer of paint and plaster without success the artist has recourse to a play of light in order to make the grey appear. There is, however, no deceit. Akin to the proposals of the film maker Harun Farocki, the image is made to reveal its process of production so as to reveal the relations thus elicited. The political possibility of the image - as Didi-Huberman seems to suggest in his analysis of

19 A consideration of this work by Hito Steyerl in the light of Adorno's explication regarding the separation between theory and praxis can be found in my article 'El color de la teoría, in the forthcoming book commemorating the 80th anniversary of the Instituto de Investigaciones Estéticas: Pablo F. Amador Marrero and Oscar Flores Flores (eds), Historia del Arte y Estudios de Cultura Visual: 80 años del Instituto de Investigaciones Estéticas (México: Instituto de Investigaciones Estéticas-UNAM, 2016. 
Farocki's work - is due to its status as a historical, technological and legal object. It is this configuration that makes possible the dismantling of its apparatus, thereby enabling a critique of violence to take place. ${ }^{20}$

Steyerl follows this schema and builds up an image, always showing how it is produced. In the film, while we see the way in which the light simulates Adorno's grey, we listen to interviews with philosophers and students, both ad hoc and from archives, as a way of revisiting the event. What took place there is of prime importance for understanding the tension between critical philosophy and mobilisations favouring direct action. The film is accompanied by an installation - remains of a wall that suggest the thing itself. We know that Steyerl did not find Adorno's grey, but the thing functioned as an invocation to rethink one of the buried histories of a friction that led to the estrangement between a critical philosopher and the social movement.

This production by Steyerl does not reflect on labour, but rather on the tension between theory and practice which, for Adorno, had as its correlative the relation between subject and object. Nonetheless, I am interested in mentioning it because it is possible to establish a relation with Gush's Red. In both cases there is a return to the thing that does not aim to be a reconstruction of the original object. Hence, just as Adorno's Grey failed to discover the grey paint of the classroom where Adorno gave his last lecture, Mandela's red Mercedes-Benz which generates a dialectical tension with the projection of Red and which the artist titled Red (Mandela car) is not Mandela's actual car. That - the original - is in the Apartheid Museum in Johannesburg. The installation that accompanies the film is a car just like Mandela's - same model and same year - which the artist has despoiled of any interior finishes, leaving only the body work. Accompanying the emptied structure of the automobile, dismounted and attached to the walls are four doors, a boot cover and a bonnet. There is no possible deceit, the parts come from different vehicles as the tones of red are not quite the same. ${ }^{21}$

What the artist seems to be doing, far from invoking a fetish, is pointing a way for the object - here the car produced in series - to lead us back to the factory, to that battlefield which was the Mercedes-Benz plant in the city of East London in the early 1990s.

Gush's work, that is to say the different parts that make up Red - film and installation - seems to offer a revocation of the myth of reconciliation. Likewise these parts seem to question the figure of Mandela, or at least remove him from the centre of the narrative. Here it is not a matter of heroes, but of battles that help us to understand the present-day conditions of labour.

The film sets off from a series of interviews where different people, both factory workers and administrators, recall events before and after the production of Mandela's red Mercedes. It is clear from all the interviews that, around the end of the 1980s and in the early 1990s, there was considerable tension in the factory arising from the social problems that affected the country. The antagonism between the workers

20 Georges Didi-Huberman, 'How to Open Your Eyes' in Antje Ehmann and Kodwo Eshun (eds), Harun Farocki: Against What? Against Whom? (London: Koening, 2010), 50.

21 See Images 1-3 of Gush's photo essay in this issue. 
(black) and the administrators (white) generated a situation of constant confrontation manifested in an unending series of strikes and stoppages in a complex trade union structure. While the production of Mandela's car supposes, in the narrative, a moment of empowerment of the workers and a sort of alliance with the factory managers, what is interesting is that Red takes us beyond that moment.

Creating tension in the narrative with a series of surface images that, in a kind of archaeology that does not aim at seeking origins but only to observe the remains of this story in the physiognomy of East London itself, the film boycotts the longing for a moment of reconciliation between narration and representation. The black and white images of these passages from the life of an industrial city that has followed a process far exceeding the symbolic fracture the memory of the individuals involved.

Gush and Cairns do not pause on the image of Mandela's car but follow the object, in its production, in order to shed light on the conflict beyond the heroic moment.

Shortly after the handing over of the red Mercedes, a fierce industrial conflict broke out in the factory. In the face of trade union restructuring aimed at generating a centralised bargaining system, a group of workers decided to maintain the strike and to organise a sleep-in in the factory that shut the plant down for nine weeks. The tension in view of the occupation and the fragmentation of positions among the workers themselves made it relatively easy for management to regain control. The occupation staged by the workers, as they later affirmed, did not really constitute industrial action in itself but was merely a form of demonstration. It was punished, however, by the sacking of more than five hundred workers. After this conflict the factory became one of the most efficient plants of Mercedes-Benz and did not witness another strike until 2013.

\section{Conclusion}

In a time of despoilment characterised by a crisis in the relation between representation, work and historical subject as the political agent, the artistic work of Gush produces an image that avoids seeking reconciliation. His work problematises the image in order to confront us with the question of how to conceive labour beyond its direct representations. Gush returns to the thing, the object that facilitates a tensing of history in the framework memory-production-testimony, so that history presents itself to us as if for the first time. The interesting thing about Red, in both the installation and the film, is that it allows the suspension of work and the worker in order to invoke, in the empty space it lays bare, forces that are irruptive for the present.

What is invoked in this work is the possibility of another kind of historical agency - participation in the image, beyond that of representations and always in a kind of antagonistic relation between image and narration. This enables us to make a claim, as Benjamin suggested, for politics to take precedence over history. Red does not attempt to fix the memory of what has been, it is the thing where the factory is the battlefield. What is important, Gush seems to suggest, is to go back to that moment in order to see just what readings of the past are unleashed.

Where the subject disappears from view, the object begins to speak. 